- FINANSE I PRAWO FINANSOWE.

- Journal of Finance and Financial Law

Czerwiec/June 2019 • vol. 2(22): 35-44

https://doi.org/10.18778/2391-6478.2.22.04

\title{
EUROPEJSKI SYSTEM NADZORU FINANSOWEGO JAKO INSTYTUCJA ZAPEWNIAJĄCA OCHRONĘ KONSUMENTÓW
}

Karolina Krzak

Koło Naukowe Zarządzania i Marketingu Uniwersytet Marii Curie-Skłodowskiej w Lublinie

\section{Streszczenie}

Celem niniejszego artykułu jest analiza organizacji oraz działania Europejskiego Systemu Nadzoru Finansowego - instytucji zapewniającej zaufanie do systemu finansowego jako całości oraz odpowiedniej ochrony konsumentów. Autor postanowił przeanalizować stwierdzenie, że Europejski System Nadzoru Finansowego jest odpowiednią instytucją nie wymagającą zmian, która zapewnia konsumentom odpowiednią ochronę. $\mathrm{W}$ artykule przedstawiono na podstawie analizy literatury przedmiotu, istotę działania Europejskiego Systemu Nadzoru Bankowego, zdefiniowano pojęcia dotyczące nadzoru finansowego oraz wskazano jak wpływa ten organ na ochronę konsumenta. Dokonano podsumowania, w którym została zawarta tabela z porównaniem instrumentów ochrony konsumenta stosowanych do poszczególnych europejskich urzędów nadzoru oraz Komisję Nadzoru Finansowego.

Słowa kluczowe: nadzór finansowy, ochrona konsumenta, Europa.

JEL Class: D18, D53. 


\section{WPROWADZENIE}

Nadzór finansowy w Unii Europejskiej zmienia się wraz ze zmianą środowiska działalności rynku finansowego. Najistotniejszym czynnikiem mającym bezpośredni wpływ na kształt nadzoru finansowego są kryzysy finansowe. Unia Europejska poprzez utworzenie jednolitego rynku finansowego na swoim obszarze przyczyniła się do powstania nowych ryzyk, które wynikają w szczególności z działalności na rynku finansowym, prowadzonej w sposób nieskrępowany na terenie całej UE [Zeszyty Naukowe Uniwersytetu Przyrodniczo-Humanistycznego...]. W latach 2007-2009 miał miejsce kryzys, który ukazał liczne niedoskonałości w zakresie funkcjonowania nadzoru finansowego w Unii Europejskiej, zarówno w odniesieniu do działalności instytucji nadzoru w poszczególnych krajach członkowskich, jak i działań nadzorczych na poziomie europejskim. W raporcie grupy de Larosière'a z 2009 r. zalecano utworzenie Europejskiego Systemu Nadzoru Finansowego (ESNF) w formie zdecentralizowanej sieci.

\section{NADZÓR FINANSOWY PRZED KRYZYSEM FINANSOWYM}

Kryzys finansowy, który miał miejsce w latach 2007-2011 przyniósł wiele zmian dotyczących nadzoru finansowego oraz działania instytucji nadzorczych. W dniach 20-23 wrzesień 2010 r. miała miejsce sesja plenarna Parlamentu Europejskiego, na której zostały przyjęte akty prawne wprowadzające nowy europejski nadzór finansowy. Rada Unii Europejskiej wyraziła zgodę dla proponowanej zmiany struktury nadzorczej i z dniem 1 stycznia 2011 r. weszła ona w życie. Reforma systemu nadzoru finansowego stanowiła całkowity przewrót w dotychczas działającej organizacji. Do 1 stycznia 2011 r. działały jeszcze komitety nadzorcze tj. Komitet Europejskich Organów Nadzoru Bankowego (CEBS) [Decyzje Komisji..., nr 2009/78/WE, Dz.Urz. UE, L 25, 21.1.200: 23], Komitet Europejskich Organów Nadzoru Ubezpieczeń i Pracowniczych Programów Emerytalnych (CEIOPS) [Decyzje Komisji..., nr 2009/79/WE, Dz.Urz. UE, L 25, 21.1.2009: 28], Komitet Europejskich Organów Nadzoru nad Rynkiem Papierów Wartościowych (CESR) [Decyzje Komisji..., 2009/77/WE, Dz.Urz. UE, L 25, 29.1.2009: 18]. Nazywane one były komitetami trzeciego poziomu procedury Lamfalussy`ego. Taka organizacja niestety nie przynosiła zamierzonych efektów. Instytucje nadzorcze działające do 1 stycznia $2011 \mathrm{r}$. raczej zbyt wolno i nieefektywnie reagowały na zagrożenia pojawiające się w systemie finansowym. W miejsce komitetów zostały powołane nowe urzędy o silnych kompetencjach. Na szczeblu unijnym został stworzony dla wszystkich państw członkowskich Unii Europejskiej nowy system, który miał przeciwdzia- 
łać kolejnym kryzysom finansowym. Głównym celem tej reformy było oczywiście zabezpieczenie rynku finansowego, ale również ochrona klientów korzystających z usług instytucji finansowych [Fedorowicz 2011a: 49-50].

\section{EUROPEJSKI SYSTEM NADZORU FINANSOWEGO}

Europejski System Nadzoru Finansowego gwarantuje precyzyjne wdrażanie przepisów dotyczących sektora finansowego, w sposób umożliwiający zachowanie stabilności finansowej, a także zapewnienie zaufania do systemu finansowego jako całości oraz odpowiedniej ochrony konsumentów [www4, dostęp: 30.03.2019].

Od dnia 1 stycznia 2011 r. funkcjonuje Europejski System Nadzoru Finansowego. Jest on zdecentralizowanym oraz wielopoziomowym systemem organów mikro- i makroostrożnościowych. W skład ESNF wchodzą europejskie i krajowe organy nadzoru. Podstawą prawną jest artykuł 21 i 114 Traktatu o funkcjonowaniu Unii Europejskiej (TFUE); art. 290 TFUE (akty delegowane); art. 291 TFUE (akty wykonawcze); art. 127 ust. 6 TFUE. Na szczeblu europejskim na filar mikroostrożnościowy [Rozporządzenie PE i Rady nr 1092/2010..., Dz.Urz. UE L 331 z 15.12.2010] składają się:

- Europejski Urząd Nadzoru Bankowego (ang. European Banking Authority $-\mathrm{EBA})$;

- Europejski Urząd Nadzoru Giełd i Papierów Wartościowych (ang. European Securities and Markets Authority - ESMA);

- Europejski Urząd Nadzoru Ubezpieczeń i Pracowniczych Programów Emerytalnych (ang. and Occupational Pensions Authority - EIOPA), które współpracują ze sobą w ramach Wspólnego Komitetu Europejskich Urzędów Nadzoru (ang. European Systemic Risk Board - ESRB). Za nadzór makroostrożnościowy odpowiedzialna jest Europejska Rada ds. Ryzyka Systemowego (ERRS). Oprócz Europejskich Urzędów Nadzoru (ang. European Supervisory Authorities - ESA) zalicza się również właściwe krajowe organy nadzoru państw członkowskich określone w odpowiednich aktach unijnych [www4, dostęp: 30.03.2019].

Jednym z głównych elementów reformy nadzoru finansowego w UE było powołanie trzech Europejskich Urzędów Nadzoru (ang. European Supervisory Authorities - ESA) w miejsce wcześniej funkcjonujących komitetów nadzorców europejskich (CEBS, CEIOPS, CESR), zwanych komitetami 3. poziomu procedury Lamfalussy'ego [Decyzje Komisji..., nr. od 2009/77/WE do 2009/79/WE, Dz.Urz. UE L 25: 18, 23, 28]. Siedziby nowopowstałych Europejskich Urzędów Nadzoru są umiejscowione w dotychczasowych siedzibach odpowiednich komitetów, czyli w Londynie, Frankfurcie oraz Paryżu. 
W skład każdego Europejskiego Urzędu Nadzoru wchodzą:

- Rada Organów Nadzoru (ang. Board of Supervisors - BoS);

- Zarząd (ang. Management Board - MB);

- Przewodniczący (ang. Chairperson);

- Dyrektor Wykonawczy (ang. Executive Director);

- Komisja Odwoławcza - wspólna dla wszystkich trzech ESA (ang. Board of Appeal - BoA).

Europejskie Urzędy Nadzoru, choć nie sprawują bezpośredniego nadzoru nad instytucjami finansowymi, mogą wydawać decyzje wiążące krajowe organy nadzoru [Fedorowicz 2010: 59-79], doradzać KE, opracowywać wytyczne, a także przeprowadzać działania w dziedzinie konwergencji praktyk nadzorczych itp. Oprócz tego, do ich kompetencji należy między innymi: kompleksowa współpraca z ESRB, śledzenie i ocena zmian na rynkach. Urzędom zostały przyznane również kompetencje związane z ochroną konsumentów, takie jak: gromadzenie $\mathrm{i}$ analizowanie informacji na temat tendencji $\mathrm{w}$ zachowaniach konsumentów oraz składanie odnośnych sprawozdań; analizowanie i koordynowanie znajomości zagadnień finansowych i inicjatyw edukacyjnych realizowanych przez właściwe organy; możliwość czasowego zakazu prowadzenia lub ograniczenia prowadzenia pewnych typów działalności finansowej, które zagrażają prawidłowemu funkcjonowaniu i integralności rynków finansowych lub stabilności całego systemu finansowego w Unii lub jego części, przypadkach określonych w aktach ustawodawczych UE.

\section{EUROPEJSKI URZĄD NADZORU BANKOWEGO}

Oprócz ogólnych informacji o ESA należy zwrócić również uwagę na poszczególne organy wchodzące w skład ESA. Pierwszym z nich jest Europejski Urząd Nadzoru Bankowego (EUNB), którego podstawą prawną jest rozporządzenie (UE) nr 1093/2010 w sprawie ustanowienia Europejskiego Urzędu Nadzoru (Europejskiego Urzędu Nadzoru Bankowego) zmienione rozporządzeniem (UE) nr 1022/2013 [Rozporządzenie PE i Rady nr 1093/2010..., Dz.Urz. UE L 331 z 15.12.2010]. Siedziba EUNB znajduje się w Paryżu. Jego głównym zadaniem jest zapewnienie skutecznej i spójnej regulacji ostrożnościowej oraz nadzór w całym europejskim sektorze bankowym [www2, dostęp: 30.03.2019]. Przewodniczący reprezentuje EUNB na zewnątrz. Do jego kompetencji należy przygotowywanie prac Urzędu i przewodzenie obradom podczas posiedzeń Rady Organów Nadzoru. Europejski Urząd Nadzoru posiada również dwa organy zarządzające: 
- Rada Organów Nadzoru, która jest głównym organem decyzyjnym Urzędu. Jej członkami [Dokumenty Informacyjne..., dostęp: 30.03.2019] są przewodniczący EUNB, naczelnik właściwego organu nadzoru z każdego państwa członkowskiego oraz po jednym przedstawicielu z Komisji, EBC, ERRS oraz dwóch pozostałych Europejskich Urzędów Nadzoru.

- Zarząd, którego obowiązkiem jest zapewnienie wypełniania przez urząd jego misji oraz wywiązanie się z powierzonych mu zadań. Zarząd posiada uprawnienia do proponowania, między innymi, rocznego programu prac, budżetu rocznego, planu polityki kadrowej oraz sprawozdania rocznego. W sprawach o charakterze międzysektorowym EUNB prowadzi ścisłą współpracę z pozostałymi Europejskimi Urzędami Nadzoru (ESA) w ramach Wspólnego Komitetu. Oprócz tego ustanowiono również Komisję Odwoławczą, która skutecznie chroni prawa stron, których dotyczą decyzje EUNB.

Ten niezależny organ od samego początku działał bardzo intensywnie. Jak wskazał w uwagach wstępnych jego przewodniczący, Urząd ,rozpoczął działalność w dość burzliwych i trudnych warunkach rynkowych, musząc niezwłocznie stawić czoła ważnym wyzwaniom. Niełatwo było skupić się na budowie nowej organizacji, będąc równocześnie zmuszonym borykać się z wielkimi zagrożeniami dla stabilności sektora bankowego" [Streszczenie sprawozdania rocznego za 2011 r., dostęp: 30.03.2019].

\section{EUROPEJSKI URZĄD NADZORU UBEZPIECZEŃ I PRACOWNICZYCH PROGRAMÓW EMERYTALNYCH}

Kolejnym organem jest Europejski Urząd Nadzoru Ubezpieczeń i Pracowniczych Programów Emerytalnych, którego podstawę prawną stanowi rozporządzenie (UE) nr 1094/2010 w sprawie ustanowienia Europejskiego Urzędu Nadzoru (Europejskiego Urzędu Nadzoru Ubezpieczeń i Pracowniczych Programów Emerytalnych) [Rozporządzenie PE i Rady nr 1094/2010..., Dz.Urz. UE L 331 z 15.12.2010]. Siedziba EIOPA znajduje się we Frankfurcie nad Menem. Głównym zadaniem urzędu EIOPA jest zapewnienie stabilności rynków ubezpieczeniowych oraz ochrona właścicieli polis, członków programów emerytalnych i uposażonych. Ponadto monitoruje on tendencje w zachowaniach konsumentów oraz ocenia potencjalne zagrożenia i słabości rynków. W ściśle określonych warunkach, ma prawo czasowo zakazać prowadzenia lub ograniczyć pewne rodzaje działalności finansowej, które zakłócają stabilność systemu finansowego. Urząd EIOPA może przeprowadzać postępowanie wyjaśniające $\mathrm{w}$ sprawie naruszenia prawa przez organ krajowy. Występuje to wtedy, gdy organ krajowy nie zapewnia spełnienia przez instytucję finansową wymogów prawa UE. W terminie dwóch miesięcy 
urząd EIOPA może skierować do organu krajowego zalecenie. Następnie Komisja może wydać formalną opinię nakładającą na właściwy organ obowiązek podjęcia działań niezbędnych do przestrzegania prawa. W przypadku nieusunięcia niezgodności przez organ krajowy, urząd EIOPA może skierować decyzję bezpośrednio do instytucji finansowej w ściśle określonych warunkach. Ta decyzja ma pierwszeństwo wobec decyzji przyjętych wcześniej przez organ krajowy [www1, dostęp: 30.03.2019].

\section{EUROPEJSKI URZĄD NADZORU GIEtD I PAPIERÓW WARTOŚCIOWYCH}

Trzecim organem jest Europejski Urząd Nadzoru Giełd i Papierów Wartościowych, którego podstawę prawną stanowi rozporządzenie (UE) nr 1095/2010 w sprawie ustanowienia Europejskiego Urzędu Nadzoru (Europejskiego Urzędu Nadzoru Giełd i Papierów Wartościowych) [Rozporządzenie PE i Rady nr 1095/2010..., Dz.Urz. UE L 331 z 15.12.2010]. Urząd ESMA ma siedzibę w Paryżu. Funkcjonuje podobnie do pozostałych Europejskich Urzędów Nadzoru, jego działalność jest związana przede wszystkim z rynkami papierów wartościowych i instytucjami uczestniczącymi.

Chroni stałości systemu finansowego UE przez zapewnianie integralności, przejrzystości, efektywności oraz przez funkcjonowanie rynków papierów wartościowych, jak również zwiększanie ochrony inwestora [www3, dostęp: 30.03.2019].

\section{WSPÓLNY KOMITET EUROPEJSKICH URZĘDÓW NADZORU}

Wspólny Komitet Europejskich Urzędów Nadzoru, odpowiada za ogólną i międzysektorową koordynację działań, mającą na celu zapewnienie międzysektorowej spójności nadzoru. Zgodnie z rozporządzeniem w sprawie Europejskich Urzędów Nadzoru, Wspólny Komitet obejmuje swą działalnością poszczególne obszary:

- konglomeraty finansowe; księgowość i audyt;

- mikroostrożnościowe analizy rozwoju sytuacji oraz zagrożeń i słabości na poziomie międzysektorowym w odniesieniu do stabilności finansowej, detaliczne produkty inwestycyjne;

- środki przeciwdziałania praniu pieniędzy;

- wymiana informacji między ERRS a Europejskimi Urzędami Nadzoru oraz rozwój stosunków między tymi instytucjami. Komitet odpowiada za rozstrzyganie sporów międzysektorowych między organami ESNF. W skład Wspólnego Komitetu wchodzą przewodniczący poszczególnych Europej- 
skich Urzędów Nadzoru (oraz ewentualnych podkomitetów), a przewodniczy mu przewodniczący jednego z Europejskich Urzędów Nadzoru, wybierany na 12-miesięczną rotacyjną kadencję. Obecnie przewodniczącym Wspólnego Komitetu jest wiceprzewodniczący ERRS. Wspólny Komitet musi spotykać się przynajmniej dwa razy w roku. Funkcję sekretariatu pełni personel Europejskich Urzędów Nadzoru [Dokumenty Informacyjne..., dostęp: 30.03.2019].

Właściwe krajowe organy nadzoru wchodzą w skład ESNF. Zgodnie $\mathrm{z}$ różnymi środkami ustawodawczymi stosowanymi w obszarze usług finansowych każde państwo członkowskie wyznacza własny właściwy organ lub właściwe organy.

\section{EUROPEJSKA RADA DS. RYZYKA SYSTEMOWEGO}

W ramach nadzoru makroostrożnościowego utworzono Europejską Radę ds. Ryzyka Systemowego [Rozporządzenie Rady nr 1096/2010 ..., Dz.Urz. UE, L 331, 15.12.2010: 162], której siedziba znajduje się we Frankfurcie nad Menem. Jest głównym organem decyzyjnym. Do jej zadań należy efektywne monitorowanie ryzyk systemowych. Ponadto przyczynia się również do sprawnego funkcjonowania rynku wewnętrznego i tym samym zapewnia trwały wkład sektora finansowego we wzrost gospodarczy. W skład Europejskiej Rady Ryzyka Systemowego wchodzą:

- Rada Generalna (ang. General Board), Komitet Sterujący (ang. Steering Committee),

- Sekretariat, Doradczy Komitet Naukowy (ang. Scientific Advisory Committee),

- Doradczy Komitet Techniczny (ang. Technical Advisory Committee).

Do członków Rady Generalnej zaliczamy wszystkich reprezentantów krajowych banków centralnych z prawem głosu. W posiedzeniach Rady biorą udział również przedstawiciele wysokiego szczebla krajowych organów nadzoru bez prawa głosu. Posiedzenia Rady odbywają się co najmniej cztery razy w roku. Komitet Sterujący wspiera proces decyzyjny ESRB przez przygotowywanie posiedzeń Rady Generalnej, monitorowanie postępów w bieżącej pracy oraz analizę dokumentów, które będą przedmiotem obrad. Za bieżącą działalność ESRB jest odpowiedzialny sekretariat, który zapewnia Radze wsparcie analityczne, administracyjne, logistyczne oraz statystyczne pod kierownictwem przewodniczącego i Komitetu Sterującego. 


\section{KOMISJA NADZORU FINANSOWEGO}

Mówiąc o Europejskim Systemie Nadzoru Finansowego należy zwrócić również uwagę na Komisję Nadzoru Finansowego (KNF) [www4, dostęp: 30.03.2019], która jest polskim organem nadzoru finansowego, wchodzącym w skład Europejskiego Systemu Nadzoru Finansowego. Trybunał Konstytucyjny uznał m.in., że w świetle regulacji ustawowych Komisja Nadzoru Finansowego jest szczególnym organem administracji państwowej o dużym stopniu niezależności, usytuowanym poza strukturą administracji rządowej [Wyrok Trybunału Konstytucyjnego..., sygn. akt K 2/09]. Takie sformułowanie należy jednak interpretować jedynie w kontekście krajowym. Chociaż KNF pozostaje niezależna w swoich działaniach od innych organów władzy publicznej w Polsce, takich jak minister finansów, pozostaje to bez wpływu na jej usytuowanie wśród organów unijnych, za który możemy ją uznać ze względu na pozostawanie części sieci organów nadzoru. W związku z tym, że prawa, obowiązki oraz skład ESA zostały uregulowane $\mathrm{w}$ rozporządzeniu unijnym, postanowienia uregulowane w tym akcie są bezpośrednio skuteczne i stosowalne również do KNF [Fedorowicz 2011b: 39 i n.].

\section{PODSUMOWANIE}

Nadzór Europejskiego Systemu Finansowego charakteryzuje się wielopoziomowym systemem organów, dzięki czemu poprawnie funkcjonuje. Poziomy tego systemu można podzielić ze względu na obszar nadzoru sektorowego i regulacji, a także szczebel, na którym odbywa się nadzór i regulacja (europejski i krajowy).

Tabela 1. Wielopoziomowy System Organów Europejskiego Systemu Nadzoru Finansowego

\begin{tabular}{|c|c|c|}
\hline \multicolumn{3}{|c|}{ Europejski System Nadzoru Finansowego } \\
\hline \multicolumn{2}{|c|}{ Organy Europejskie } & \multirow{2}{*}{ Organy krajowe w Polsce } \\
\hline Filar mikrostrożnościowy & Filar makroostrożnościowy & \\
\hline \begin{tabular}{|c|} 
- Europejski Urząd Nadzoru \\
Bankowego (EBA) \\
- Europejski Urząd Nadzoru Giełd \\
i Papierów Wartościowych \\
(ESMA) \\
- Europejski Urząd Nadzoru \\
Ubezpieczeń i Pracowniczych \\
Programów Emerytalnych (EIOPA
\end{tabular} & $\begin{array}{c}\text { - Rada ds. Ryzyka Systemo- } \\
\text { wego (ERRS) }\end{array}$ & $\begin{array}{c}\text { - Komisja Nadzoru Finansowe- } \\
\text { go (KNF) }\end{array}$ \\
\hline
\end{tabular}

Źródło: opracowanie własne na podstawie art. 21 i 114 Traktatu o funkcjonowaniu Unii Europejskiej (TFUE); art. 290 TFUE (akty delegowane); art. 291 TFUE (akty wykonawcze); art. 127 ust. 6 TFUE. 
Działania poszczególnych podmiotów $\mathrm{w}$ ramach ESNF są koordynowane również z działaniami różnych instytucji na szczeblu każdego kraju członkowskiego. Z tego tytułu utworzono różne organy oraz instrumenty koordynujące, które mają za zadanie zapewnić spójność i zgodność między poszczególnymi poziomami [Dokumenty Informacyjne..., dostęp: 30.03.2019]. Należy również podkreślić, że EUNB, EIOPA i ESMA to niezależne organy UE, działające wyłącznie w interesie całej Unii, posiadające osobowość prawną oraz reprezentowane przez swoich przewodniczących. Dzięki wprowadzeniu w życie założeń komisji de Larosiere'a, sytuacja nadzoru finansowego Unii Europejskiej poprawiła jakość swojej działalności. ESNF zapewnia odpowiednie wdrażanie przepisów w sposób zapewniający utrzymanie stabilności systemu finansowego, odbudowę zaufania i ochronę konsumentów usług finansowych, co jest oceniane przeze mnie pozytywnie. Myślę, że na chwilę obecną nie są potrzebne żadne zmiany w strukturze organów współpracujących w ramach Europejskiego Systemu Nadzoru Finansowego. A dość krótki staż działania tej instytucji na chwilę obecną nie ujawnia żadnych uchybień w wypełnianiu swoich działań.

\section{BIBLIOGRAFIA}

Decyzje Komisji z dnia 23.01.2009 r. nr od 2009/77/WE do 2009/79/WE [Dz.Urz. UE L 25].

Dokumenty Informacyjne o Unii Europejskiej, 2019, http:/www.europarl.europa.eu [dostęp: 30.03.2019].

Fedorowicz M., 2010, Funkcje nowego europejskiego nadzoru finansowego ze szczególnym uwzględnieniem funkcji nadzorczych w sektorze bankowym, „Kwartalnik Prawa Publicznego", $\mathrm{nr} 4$.

Fedorowicz M., 2011a, Porównanie koncepcji normatywnych nowego europejskiego nadzoru finansowego oraz Europejskiego Systemu Banków Centralnych - wybrane zagadnienia, Poznań.

Fedorowicz M., 2011b, Współpraca między Europejskimi Urzędami Nadzoru Finansowego a Komisja Nadzoru Finansowego w zakresie nadzoru nad rynkiem finansowym w UE, [w:] E. Fojcik-Mastalska, E. Rutkowska-Tomaszewska (red.), Nadzór nad rynkiem finansowym: aktualne tendencje i problemy dyskusyjne, Wrocław.

Rozporządzenie PE i Rady nr 1092/2010 z 24.11.2010 w sprawie unijnego nadzoru makroostrożnościowego nad systemem finansowym i ustanowienia Europejskiej Rady ds. Ryzyka Systemowego [Dz.Urz. UE L 331 z 15.12.2010].

Rozporządzenie PE i Rady nr 1093/ 2010 z 24.11.2010 r. w sprawie ustanowienia Europejskiego Urzędu Nadzoru (Europejskiego Urzędu Nadzoru Bankowego), zmiany decyzji nr 716/2009/WE oraz uchylenia decyzji Komisji 2009/78/WE, [Dz.Urz. UE L 331 z 15.12.2010].

Rozporządzenie PE i Rady nr 1094/2010 z 24.11.2010 w sprawie ustanowienia Europejskiego Urzędu Nadzoru (Europejskiego Urzędu Nadzoru Ubezpieczeń i Pracowniczych Programów Emerytalnych), zmiany decyzji nr 716/2009/WE i uchylenia decyzji Komisji 2009/79/WE, [Dz.Urz. UE L 331 z 15.12.2010]. 
Rozporządzenie PE i Rady nr 1095/2010 z 24.11.2010 w sprawie ustanowienia Europejskiego Urzędu Nadzoru (Europejskiego Urzędu Nadzoru Giełd i Papierów Wartościowych), zmiany decyzji nr 716/2009/WE i uchylenia decyzji Komisji 2009/77/WE, [Dz. Urz. UE L 331 z 15.12.2010].

Rozporządzenie Rady nr 1096/2010 z 17.11.2010 r. w sprawie powierzenia Europejskiemu Bankowi Centralnemu szczególnych zadań w zakresie funkcjonowania Europejskiej Rady ds. Ryzyka Systemowego [Dz.Urz. UE, L 331, 15.12.2010].

Streszczenie sprawozdania rocznego za $2011 \mathrm{r}$., https://www.eba.europa.eu/documents/10180/25763/2011-EBA-AR---PL.pdf/aa502a37-8602-4934-a262-a952e20bf0cc [dostęp: 30.03.2019].

Wyrok Trybunału Konstytucyjnego z 15 czerwca 2011 r. w sprawie K 2/09, Dz. U. Nr 134, poz. 788.

[www1] https://eur-lex.europa.eu/legal-content/PL/TXT/?uri=CELEX:32010R1092 [dostęp: 30.03.2019].

[www2] https://www.eba.europa.eu/languages/home_pl [dostęp: 30.03.2019].

[www3] http://www.esma.europa.eu/page/esma-short [dostęp: 30.03.2019].

[www4] https://www.knf.gov.pl/o_nas/wspolpraca_miedzynarodowa/unia/ESNF/inf_ogol [dostęp: 30.03.2019].

Zeszyty Naukowe Uniwersytetu Przyrodniczo-Humanistycznego w Siedlcach Nr 97 Seria: Administracja i Zarządzanie 2013.

\title{
EUROPEAN SYSTEM OF FINANCIAL SUPERVISION AS AN INSTITUTION PROVIDING CONSUMERS PROTECTION
}

\begin{abstract}
The purpose of this article is to analyze of the organization and operation of the European System of Financial Supervision - an institution that ensures trust in the financial system as a whole and adequate protection of consumers. The autor decided to analyze the statement that European System of Financial Supervision is an appropriate institution that does not require changes, which provides consumers with adequate protection.
\end{abstract}

Keywords: financial supervision, consumer protection, Europe. 